Article

\title{
Ring-Expansion Reaction of Oximes with Aluminum Reductants
}

Hidetsura Cho ${ }^{1,2, *}$, Yusuke Iwama ${ }^{2}$, Nakako Mitsuhashi ${ }^{2}$, Kenji Sugimoto ${ }^{2}$, Kentaro Okano ${ }^{2}$ and Hidetoshi Tokuyama ${ }^{2, *}$

1 Graduate School of Science, Tohoku University, 6-3 Aoba, Aramaki, Aoba-ku, Sendai 980-8578, Japan

2 Graduate School of Pharmaceutical Sciences, Tohoku University, 6-3 Aoba, Aramaki, Aoba-ku, Sendai 980-8578, Japan

* Authors to whom correspondence should be addressed;

E-Mails: hcho@mail.pharm.tohoku.ac.jp (H.C.); tokuyama@mail.pharm.tohoku.ac.jp (H.T.); Tel.: +81-22-795-6887 (H.T.); Fax: +81-22-795-6877 (H.T.).

Received: 5 April 2012; in revised form: 4 June 2012 / Accepted: 7 June 2012 /

Published: 14 June 2012

Abstract: The ring-expansion reactions of heterocyclic ketoximes and carbocyclic ketoximes with several reductants such as $\mathrm{AlHCl}_{2}, \mathrm{AlH}_{3}$ (alane), $\mathrm{LiAlH}_{4}, \mathrm{LiAlH}\left(\mathrm{O}{ }^{t} \mathrm{Bu}\right)_{3}$, and $\left(\mathrm{MeOCH}_{2} \mathrm{CH}_{2} \mathrm{O}\right)_{2} \mathrm{AlH}_{2} \mathrm{Na}$ (Red-Al) were examined. Among reductants, $\mathrm{AlHCl}_{2}$ $\left(\mathrm{LiAlH}: \mathrm{AlCl}_{3}=1: 3\right)$ in cyclopentyl methyl ether (CPME) has been found to be a suitable reagent for the reaction, and the rearranged cyclic secondary amines were obtained in good to excellent yields.

Keywords: aluminum reductant; dichloroaluminum hydride $\left(\mathrm{AlHCl}_{2}\right)$; ring-expansion of oxime; rearrangement of oxime; cyclopentyl methyl ether (CPME)

\section{Introduction}

The development of novel synthetic method of constructing basic heterocyclic skeletons is an important research topic from the viewpoint of both synthetic chemistry and medicinal chemistry. Specifically, the fundamental skeletons containing a nitrogen functionality attached to an aromatic ring are of great importance because they are often used as the core structures of medicines or clinical candidates. In this research area, we have recently reported the synthesis of five- to eight-membered bicyclic or tricyclic fused heterocycles containing nitrogen attached to an aromatic ring by the 
reductive ring expansion reaction of cyclic ketoximes or hydroxylamines using diisobutylaluminum hydride [DIBALH: $\left.\left({ }^{i} \mathrm{Bu}\right)_{2} \mathrm{AlH}\right]$ [1-6]. We also carried out mechanistic studies to prove the intermediacy of the corresponding hydroxylamines and to obtain mechanistic information about the ring expansion on the basis of DFT calculations [3].

However, we have not yet performed systematic examinations of suitable reductants and solvents for the reductive ring expansion reaction. A similar reaction using borane was in fact reported by Ortiz-Marciales et al. The reductive ring expansion of $O$-silylated oximes proceeded using borane in the presence of boron trifluoride [7]. In this report, we disclose our recent results on the reductive ring-expansion reactions of oximes with a variety of aluminum reductants.

\section{Results and Discussion}

We selected five reductants, i.e., lithium aluminum hydride $\left(\mathrm{LiAlH}_{4}\right)$ [8,9], aluminum hydride $\left(\mathrm{AlH}_{3}\right.$; alane) [9-11], sodium bis(2-methoxyethoxy)aluminum hydride (Red-Al; Vitride) [12], dichloroaluminum hydride $\left(\mathrm{AlHCl}_{2}\right)$ [9-11,13], lithium tri-tert-butoxyaluminum hydride $\left[\mathrm{LiAlH}\left(\mathrm{O}{ }^{t} \mathrm{Bu}\right)_{3}\right]$, and compared their reactivities using the oxime 1a as the test substrate (Table 1).

Table 1. Rearrangement of oxime with various reductants.<smiles>ON=C1CCSc2ccccc21</smiles>

$1 a$

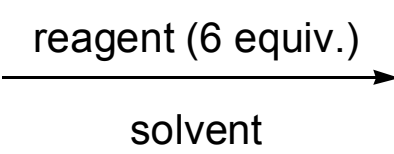

solvent<smiles>c1ccc2c(c1)NCCCS2</smiles>

$2 a$<smiles>NC1CCSc2ccccc21</smiles>

$3 a$

\begin{tabular}{ccccccc}
\hline Entry & Reagent & Solvent & Temp. & Time & 2a (\%) & 3a (\%) \\
\hline 1 & $\mathrm{LiAlH}_{4}$ & $\mathrm{Et}_{2} \mathrm{O}$ & $0{ }^{\circ} \mathrm{C}$ to rt & $5 \mathrm{~h}$ & 29 & 45 \\
2 & $\left(\mathrm{MeOCH} \mathrm{CH}_{2} \mathrm{O}\right)_{2} \mathrm{AlH}_{2} \mathrm{Na}$ & toluene & 0 to $50{ }^{\circ} \mathrm{C}$ & $5 \mathrm{~h}$ & 31 & 18 \\
3 & $\left.\mathrm{LiAlH}^{t} \mathrm{O}^{t} \mathrm{Bu}\right)_{3}$ & $\mathrm{Et}_{2} \mathrm{O}$ & $0{ }^{\circ} \mathrm{C}$ to reflux & $24 \mathrm{~h}$ & 0 & 0 \\
4 & $\mathrm{AlH}_{3}$ & $\mathrm{Et}_{2} \mathrm{O}$ & $0{ }^{\circ} \mathrm{C}$ to rt & $2 \mathrm{~h}$ & 46 & 47 \\
5 & $\mathrm{AlHCl}_{2}$ & $\mathrm{Et}_{2} \mathrm{O}$ & $0{ }^{\circ} \mathrm{C}$ to rt & $2 \mathrm{~h}$ & 72 & 6 \\
6 & $\mathrm{AlHCl}_{2}$ & $\mathrm{CPME}$ & $0{ }^{\circ} \mathrm{C}$ to rt & $2 \mathrm{~h}$ & 76 & 0 \\
\hline
\end{tabular}

When 1a was treated with six mol equiv. of $\mathrm{LiAlH}_{4}$, the desired ring expansion product, 2,3,4,5tetrahydrobenzo $[b][1,4]$ thiazepine (2a) was obtained in only $29 \%$ yield and was associated with substantial amounts of the primary amine 3a [14], which should be generated by the $\mathrm{C}=\mathrm{N}$ and $\mathrm{N}-\mathrm{O}$ reduction of the oxime (Entry 1). Reaction with Red-Al gave similar results providing a mixture of 2a (31\%) and 3a (18\%) (Entry 2). $\mathrm{LiAlH}\left(\mathrm{O}^{t} \mathrm{Bu}\right)_{3}$, on the other hand, was considerably less reactive and produced no product (Entry 3). Next, we examined $\mathrm{AlH}_{3}$ and $\mathrm{AlHCl}_{2}$, which possess Lewis acidic character. When 1a was treated with six mol equiv. of $\mathrm{AlH}_{3}$ in $\mathrm{Et}_{2} \mathrm{O}$, a result parallel to those of $\mathrm{LiAlH}_{4}$ and Red-Al was obtained. Thus, a mixture of $\mathbf{2 a}$ and $\mathbf{3 a}$ in $46 \%$ and in $47 \%$ yield, respectively, was isolated (Entry 4). Interestingly, however, the treatment of the ketoxime 1a with six mol equiv. of $\mathrm{AlHCl}_{2}$, which was prepared as a suspension in $\mathrm{Et}_{2} \mathrm{O}$, afforded 2a in $72 \%$ yield associated with only a small amount of the primary amine 3a (6\%) (Entry 5). The smooth ring expansion after 1,2-reduction may be attributed to the Lewis acidity of $\mathrm{AlHCl}_{2}$ etc., which should coordinate with the oxygen of the 
hydroxylamine A to promote a rearrangement process via intermediate B (Scheme 1) [3]. Having found that $\mathrm{AlHCl}_{2}$ is a suitable reductant to promote the ring expansion reaction, we then investigated this generality along with solvent effects. As to reaction solvents, several solvents such as $\mathrm{Et}_{2} \mathrm{O},{ }^{i} \operatorname{Pr}_{2} \mathrm{O}$, THF, cyclopentyl methyl ether (CPME) $[15,16]$ and mixed solvents were examined. Among them, the use of CPME was found to suppress the formation of undesired 3a to provide 2a in $76 \%$ yield (Entry 6). CPME is an alternative to conventional ethereal solvents, such as THF and diethyl ether, due to a higher solubility for substrates, the superior handling, and safety for a large-scale production [15].

Scheme 1. Proposed mechanisms of reductive ring expansion reaction of ketoximes with the aluminum reagent.<smiles>O/N=C1\CCSc2ccccc21</smiles>

$1 a$

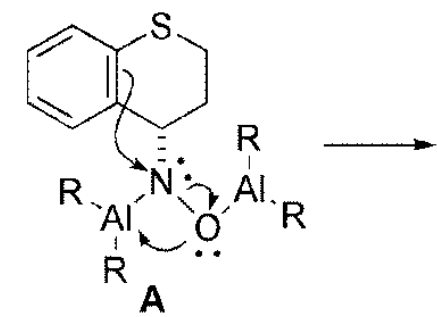

A

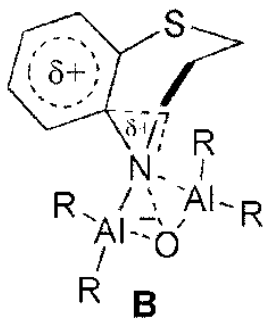

B

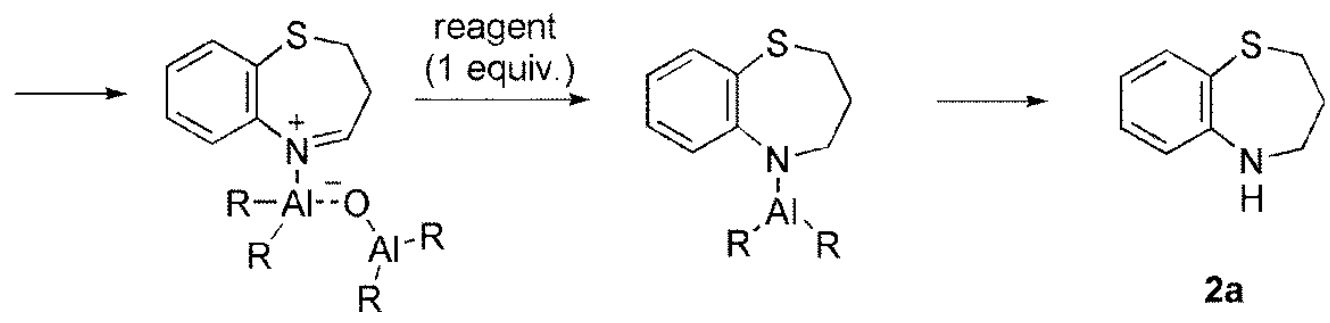

The generality of CPME was examined using a variety of cyclic ketoximes (Table 2). Although the reaction of $\mathbf{1 b}$ in CPME provided 2,3,4,5-tetrahydrobenzo[b][1,4]oxazepine (2b) in slightly lower yield than in $\mathrm{Et}_{2} \mathrm{O}$ (Entry 2), reactions using 1a, 1c, and 1d in CPME afforded 2,3,4,5-tetrahydrobenzo $[b][1,4]$ thiazepine (2a), 2,3,4,5-tetrahydro- $1 H$-benz[ $b]$ azepine (2c), and 5,6,7,8-tetrahydro- $4 H$ thieno[3,2-b]azepine (2d) in much better yields (Entries 1, 3, and 4), respectively. In addition, the reactions of aryl oximes $\mathbf{1 e}$ and $\mathbf{1 f}$ furnished the desired tetrahydrobenzoazepines $\mathbf{2 e}$ and $\mathbf{2} \mathbf{f}$ in good to excellent yields (Entries 5 and 6). Subsequently, we applied the reaction to five- or seven-membered oximes. While the reaction of $\mathbf{1} \mathbf{g}$ in $\mathrm{Et}_{2} \mathrm{O}$ gave 1,2,3,4-tetrahydroquinoline (2g) in moderate yield because of the recovered starting material, the reaction in CPME provided $\mathbf{2} \mathbf{g}$ in better yields than in $\mathrm{Et}_{2} \mathrm{O}$ (Entry 7). The treatment of $\mathbf{1 h}$ with $\mathrm{AlHCl}_{2}$ in $\mathrm{CPME}$ also gave 1,2,3,4,5,6-hexahydrobenz $[b]$ azocine (2h) in good yield (Entry 8).

Table 2. Rearrangement of oxime with dichloroaluminum hydride.

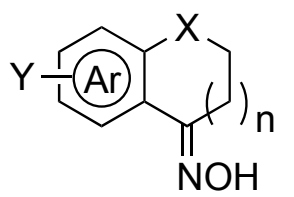

$1 \mathrm{n}=0,1,2$

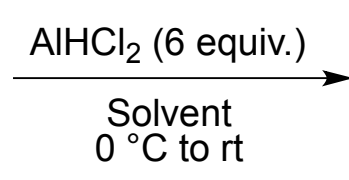

Solvent

${ }^{\circ} \mathrm{C}$ to $\mathrm{rt}$

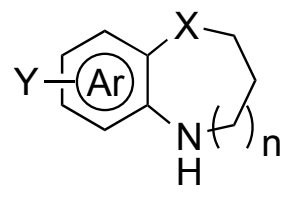

$2 \mathrm{n}=0,1,2$ 
Table 2. Cont.

Entry

\section{Experimental}

\subsection{General}

All the melting points were determined with a Yanaco micro melting point apparatus and are uncorrected. IR spectra were measured with a Shimadzu FTIR-8300 spectrometer. NMR spectra (at $400 \mathrm{MHz}$ for ${ }^{1} \mathrm{H}$ and $100 \mathrm{MHz}$ for ${ }^{13} \mathrm{C}$ ) were recorded on a JEOL JNM-Al 400 spectrometer with tetramethylsilane $(0 \mathrm{ppm})$ or chloroform $(7.24 \mathrm{ppm})$ as the internal standard. Mass spectra were recorded on JMS-DX303, JMS-700, or JMS-T100GC spectrometers. Elemental analyses were performed with a Yanaco CHN CORDER MT-6. Column chromatography was performed on silica gel 60N (Kanto, 63-210 $\mu \mathrm{m}$ ), and flash column chromatography was performed on silica gel $60 \mathrm{~N}$ (Kanto, 40-60 $\mu \mathrm{m}$ ) using the indicated solvents. Reactions and chromatography fractions were monitored by using precoated silica gel $60 \mathrm{~F}_{254}$ plates (Merck). 


\subsection{General Preparation of $\mathrm{AlHCl}_{2}$ and $\mathrm{AlH}_{3}$ in Accordance with the Procedure Reported by} Ashby et al. $[10,11]$

Four mol equiv. of $\mathrm{AlHCl}_{2}$ (containing one mol equiv. of $\mathrm{LiCl}$ ) was prepared in $\mathrm{Et}_{2} \mathrm{O}$ or $\mathrm{CPME}$ at $0{ }^{\circ} \mathrm{C}$ from one mol equiv. of $\mathrm{LiAlH}_{4}$, and three mol equiv. of $\mathrm{AlCl}_{3}$. Four mol equiv. of $\mathrm{AlH}_{3}$ (containing three mol equiv. of $\mathrm{LiCl}$ ) was prepared in $\mathrm{Et}_{2} \mathrm{O}$ from three mol equiv. of $\mathrm{LiAlH}_{4}$ and one mol equiv. of $\mathrm{AlCl}_{3}$.

3.2.1. Synthesis of 2,3,4,5-tetrahydrobenzo[ $b][1,4]$ thiazepine (2a) and 3,4-dihydro- $2 H$-thiochromen-4ylamine (3a)

Reaction of 1a with 6.0 mol equiv. of $\mathrm{AlHCl}_{2}$ in CPME (Table 2, Entry 1). A flame-dried 30-mL two-necked round-bottomed flask equipped with a magnetic stirring bar was charged with $\mathrm{LiAlH}_{4}$ (15.0 mg, $395 \mu \mathrm{mol})$. The $\mathrm{LiAlH}_{4}$ in the flask was stirred at $0{ }^{\circ} \mathrm{C}$. A dry CPME $(1.5 \mathrm{~mL})$ solution of $\mathrm{AlCl}_{3}(159 \mathrm{mg}, 1,190 \mu \mathrm{mol})$ from a flame-dried 10-mL two-necked round-bottomed flask was slowly added to the reaction mixture over a period of $5 \mathrm{~min}$ by cannulation. The reaction mixture was stirred at $0{ }^{\circ} \mathrm{C}$ for $2 \mathrm{~h}$. Thiochroman-4-one oxime (1a, $\left.47.3 \mathrm{mg}, 264 \mu \mathrm{mol}\right)$ in dry CPME $(2.5 \mathrm{~mL})$ from a flame-dried 10-mL two-necked round-bottomed flask was added slowly to the reaction mixture over a period of $5 \mathrm{~min}$ by cannulation. After stirring for $10 \mathrm{~min}$ at $0{ }^{\circ} \mathrm{C}$, the reaction mixture was warmed to room temperature, stirred for another $2 \mathrm{~h}$, cooled to $0{ }^{\circ} \mathrm{C}$, and then treated carefully with wet $\mathrm{Et}_{2} \mathrm{O}(2 \mathrm{~mL})$ and water $(2 \mathrm{~mL})$. The mixture was made basic with $1 \mathrm{M}$ aqueous potassium hydroxide $(5 \mathrm{~mL})$ and extracted with ethyl acetate. The combined organic extracts were dried over anhydrous sodium sulfate and filtered. The filtrate was concentrated under reduced pressure. The residue was purified twice by preparative TLC (hexane/EtOAc $=5: 1)$ to afford pure 2,3,4,5-tetrahydrobenzo[b][1,4] thiazepine (2a) (33.2 $\mathrm{mg}, 201 \mu \mathrm{mol}, 76 \%$ ) as a yellow oil. To a solution of $\mathbf{2 a}$ in $\mathrm{Et}_{2} \mathrm{O}$ was added hydrochloric acid in $\mathrm{Et}_{2} \mathrm{O}(1 \mathrm{M})$ at room temperature. After stirring, $\mathrm{Et}_{2} \mathrm{O}$ was removed under reduced pressure. The residue was purified by recrystallization to give the hydrochloric acid salt of $\mathbf{2 a}$ as colorless crystals.

2,3,4,5-Tetrahydrobenzo[b][1,4]thiazepine (2a) hydrochloride. M.p.: $138-142{ }^{\circ} \mathrm{C}$ (from EtOH), m.p. 142-144 ${ }^{\circ} \mathrm{C}$ (from $i$-PrOH). ${ }^{1} \mathrm{H}-\mathrm{NMR}\left(\mathrm{CD}_{3} \mathrm{OD}\right): \delta 7.74(\mathrm{dd}, 1 \mathrm{H}, J=1.6$ and $7.6 \mathrm{~Hz}), 7.56(\mathrm{dd}, 1 \mathrm{H}$, $J=1.6$ and $7.6 \mathrm{~Hz}$ ), 7.51 (ddd, $1 \mathrm{H}, J=1.6,7.6$ and $7.6 \mathrm{~Hz}$ ), 7.46 (ddd, $1 \mathrm{H}, J=1.6,7.6$ and $7.6 \mathrm{~Hz}$ ), $3.51(\mathrm{t}, 2 \mathrm{H}, J=5.6 \mathrm{~Hz}), 2.95(\mathrm{t}, 2 \mathrm{H}, J=5.6 \mathrm{~Hz}), 2.40(\mathrm{tt}, 2 \mathrm{H}, J=5.6$ and $5.6 \mathrm{~Hz}) .{ }^{13} \mathrm{C}-\mathrm{NMR}\left(\mathrm{CD}_{3} \mathrm{OD}\right)$ : $\delta 140.9,136.0,132.6,131.3,131.0,124.7,50.9,32.7,29.9 . \mathrm{IR}\left(\mathrm{KBr}, \mathrm{cm}^{-1}\right): 2914,2687,1558,1456$, 764. Elemental analysis: calcd. (\%) for $\mathrm{C}_{9} \mathrm{H}_{12} \mathrm{ClNS}$ : C 53.59, H 6.00, N 6.94. Found: C 53.47, H 5.85, N 6.89.

Orlova et al. carried out the reaction of $\mathbf{1 a}$ with the reagent $\mathrm{LiAlH}_{4}-\mathrm{AlCl}_{3}(1: 4,4$ equiv. to 1a) and described that 2a was obtained in $80.5 \%$ yield. The melting point (m.p. $202-204{ }^{\circ} \mathrm{C}$ from $i$-PrOH) of the $\mathrm{HCl}$ salts reported is different from our $\mathrm{HCl}$ salts (m.p. $142-144{ }^{\circ} \mathrm{C}$ from $i$ - $\mathrm{PrOH}$ ) [13].

Reaction of 1a with 6.1 mol equiv. of $\mathrm{LiAlH}_{4}$ (Table 1, Entry 1). A flame-dried 10-mL two-necked round-bottomed flask equipped with a magnetic stirring bar was charged with $\mathrm{LiAlH}_{4}(23.2 \mathrm{mg}$, $610 \mu \mathrm{mol})$. The $\mathrm{LiAlH}_{4}$ in the flask was stirred at $0{ }^{\circ} \mathrm{C}$. To the stirred $\mathrm{LiAlH}_{4}$ was added dry $\mathrm{Et}_{2} \mathrm{O}(1.0 \mathrm{~mL})$. To the suspension was added $1 \mathrm{a}(18.2 \mathrm{mg}, 100 \mu \mathrm{mol})$. After stirring for $0.5 \mathrm{~h}$ at $0{ }^{\circ} \mathrm{C}$, the reaction mixture was warmed to room temperature, stirred for another $6 \mathrm{~h}$, cooled to $0{ }^{\circ} \mathrm{C}$, and then treated 
carefully with wet $\mathrm{Et}_{2} \mathrm{O}(1 \mathrm{~mL})$ and water $(1 \mathrm{~mL})$. The mixture was made basic with $2 \mathrm{M}$ aqueous $\mathrm{NaOH}(2 \mathrm{~mL})$ and extracted with $\mathrm{Et}_{2} \mathrm{O}$. The combined organic extracts were washed with brine, dried over anhydrous sodium sulfate, and filtered. The filtrate was concentrated under reduced pressure. The residue was purified by preparative TLC (hexane/ $\left.\mathrm{Et}_{2} \mathrm{O}=3: 1\right)$ to afford $\mathbf{2 a}(4.8 \mathrm{mg}, 29 \mu \mathrm{mol}, 29 \%)$ and 3a (7.4 mg, $45 \mu \mathrm{mol}, 45 \%)$.

3,4-Dihydro-2H-thiochromen-4-ylamine (3a) [14]; ${ }^{1} \mathrm{H}-\mathrm{NMR}\left(\mathrm{CDCl}_{3}\right)$ : $\delta 7.32-7.23(\mathrm{~m}, 1 \mathrm{H}), 7.16-7.00$ (m, 3H), 4.05 (brs, 1H), 3.31-3.19 (m, 1H), 2.98-2.87 (m, 1H), 2.17-2.05 (m, 2H), 1.62 (br s, 2H). ${ }^{13} \mathrm{C}-\mathrm{NMR}\left(\mathrm{CDCl}_{3}\right): \delta 137.4,132.3,129.2,127.4,126.7,124.2,48.4,31.0,22.1$. IR (neat, $\left.\mathrm{cm}^{-1}\right): 2920$, 2849, 1583, 1566, 1472, 1435, 1286, 1074, 1042, 887, 754, 731. HRMS-EI calcd. for $\mathrm{C}_{9} \mathrm{H}_{11} \mathrm{NS}_{\left(\mathrm{M}^{+}\right)}$ 165.0612. Found: 165.0608.

Reaction of 1a with $6.0 \mathrm{~mol}$ equiv. of Red-Al (Table 1, Entry 2). A two-necked 10-mL round-bottomed flask equipped with a magnetic stirring bar was charged with 1a $(18.0 \mathrm{mg}, 100 \mu \mathrm{mol})$ and dry toluene $(1 \mathrm{~mL})$. The solution was cooled to $0{ }^{\circ} \mathrm{C}$. To the solution was added Red-Al $(76 \mu \mathrm{L}$, $\geq 65 \mathrm{wt} \%$ in toluene, $600 \mu \mathrm{mol}$ ) at $0{ }^{\circ} \mathrm{C}$, and the resulting mixture was stirred at room temperature for $0.5 \mathrm{~h}$. The reaction mixture was heated at $50{ }^{\circ} \mathrm{C}$ for $6 \mathrm{~h}$, cooled to $0{ }^{\circ} \mathrm{C}$, and then treated carefully with wet $\mathrm{Et}_{2} \mathrm{O}(1 \mathrm{~mL})$ and water $(1 \mathrm{~mL})$. The mixture was made basic with $2 \mathrm{M}$ aqueous $\mathrm{NaOH}(2 \mathrm{~mL})$ and extracted with $\mathrm{Et}_{2} \mathrm{O}$. The combined organic extracts were washed with brine, dried over anhydrous sodium sulfate, and filtered. The filtrate was concentrated under reduced pressure. The residue was purified by preparative TLC (hexane/ $\left.\mathrm{Et}_{2} \mathrm{O}=3: 1\right)$ to afford 2a $(5.1 \mathrm{mg}, 31 \mu \mathrm{mol}, 31 \%)$ and $\mathbf{3 a}(2.9 \mathrm{mg}$, $18 \mu \mathrm{mol}, 18 \%$ ). Orlova and Kucherova reported the reaction of $1 \mathrm{a}$ with Red-Al, but they simply noted the reaction in only 12 lines and no details were given [12].

Reaction of 1 a with 5.9 mol equiv. of $\mathrm{AlH}_{3}$ (Table 1, Entry 4). A flame-dried 10-mL two-necked round-bottomed flask equipped with a magnetic stirring bar was charged with $\mathrm{LiAlH}_{4}(16.8 \mathrm{mg}, 443 \mu \mathrm{mol})$. The $\mathrm{LiAlH}_{4}$ in the flask was stirred at $0{ }^{\circ} \mathrm{C}$. To the stirred $\mathrm{LiAlH}_{4}$ was added dry $\mathrm{Et}_{2} \mathrm{O}(1.0 \mathrm{~mL})$ and $\mathrm{AlCl}_{3}(23.2 \mathrm{mg}, 170 \mu \mathrm{mol})$. The reaction mixture was stirred at $0^{\circ} \mathrm{C}$ for $1 \mathrm{~h}$. To the suspension was added $1 \mathrm{a}(18.2 \mathrm{mg}, 100 \mu \mathrm{mol})$. After stirring for $0.5 \mathrm{~h}$ at $0{ }^{\circ} \mathrm{C}$, the reaction mixture was warmed to room temperature, stirred for another $2 \mathrm{~h}$, cooled to $0{ }^{\circ} \mathrm{C}$, and then treated carefully with wet $\mathrm{Et}_{2} \mathrm{O}(1 \mathrm{~mL})$ and water $(1 \mathrm{~mL})$. The mixture was made basic with $2 \mathrm{M}$ aqueous $\mathrm{NaOH}(2 \mathrm{~mL})$ and extracted with $\mathrm{Et}_{2} \mathrm{O}$. The combined organic extracts were washed with brine, dried over anhydrous sodium sulfate, and filtered. The filtrate was concentrated under reduced pressure. The residue was purified by preparative TLC (hexane/ $\mathrm{Et}_{2} \mathrm{O}=3: 1$ ) to afford $\mathbf{2 a}(7.6 \mathrm{mg}, 46 \mu \mathrm{mol}, 46 \%)$ and $\mathbf{3 a}(7.8 \mathrm{mg}, 47 \mu \mathrm{mol}, 47 \%)$.

\subsubsection{Synthesis of 5,6,7,8-tetrahydro-4H-thieno[3,2-b]azepine (2d)}

Reaction of $1 \mathbf{d}$ with 6.0 mol equiv. of $\mathrm{AlHCl}_{2}$ in CPME (Table 2, Entry 4). To a flame-dried 100-mL two-necked round-bottomed flask equipped with a magnetic stirring bar were successively added $\mathrm{LiAlH}_{4}(65.1 \mathrm{mg}, 1.72 \mathrm{mmol})$, anhydrous CPME $(10 \mathrm{~mL})$, and $\mathrm{AlCl}_{3}(682 \mathrm{mg}, 5.11 \mathrm{mmol})$ at $0{ }^{\circ} \mathrm{C}$. Stirring was continued at $0{ }^{\circ} \mathrm{C}$ for $1 \mathrm{~h}$. 6,7-Dihydro-4-benzo[b]thiophenone oxime $(1 \mathrm{~d}, 167 \mathrm{mg}$, $1.00 \mathrm{mmol}$ ) was added in a small portion. After stirring for $0.5 \mathrm{~h}$ at $0{ }^{\circ} \mathrm{C}$, the reaction mixture was warmed to room temperature, stirred for another $2.5 \mathrm{~h}$, cooled to $0{ }^{\circ} \mathrm{C}$, and then treated carefully with wet $\mathrm{Et}_{2} \mathrm{O}(10 \mathrm{~mL})$ and $2 \mathrm{M}$ aqueous $\mathrm{NaOH}(20 \mathrm{~mL})$. The mixture was extracted with $\mathrm{Et}_{2} \mathrm{O}$ and the 
combined organic extract was washed with brine, dried over anhydrous sodium sulfate, and filtered. The filtrate was concentrated under reduced pressure to give the residue, which was purified by silica gel column chromatography (hexanes/EtOAc $=3: 1$ ) to afford 5,6,7,8-tetrahydro-4H-thieno[3,2b]azepine (2d, $135 \mathrm{mg}, 0.881 \mathrm{mmol}, 88 \%$ ) as a yellow oil [1].

\section{Conclusions}

The examination of the reductive ring-expansion reaction of cyclic ketoximes using a variety of aluminum reductants, i.e., $\mathrm{LiAlH}_{4}, \mathrm{LiAlH}\left(\mathrm{O}^{t} \mathrm{Bu}\right)_{3}, \mathrm{Red}-\mathrm{Al}, \mathrm{AlHCl}_{2}$, and $\mathrm{AlH}_{3}$, revealed that dichloroaluminum hydride $\left(\mathrm{AlHCl}_{2}\right)\left(\mathrm{LiAlH}_{4} / \mathrm{AlCl}_{3}=1: 3\right)$ is a suitable reagent for promoting the reaction and affords ring expansion products in good to excellent yields. In addition, it was clarified that CPME could be effective solvent than $\mathrm{Et}_{2} \mathrm{O}$ for the rearrangement of cyclic ketoximes with $\mathrm{AlHCl}_{2}$. The finding may lead to further synthetic application of variously substituted heterocyclic compounds and complicated medicine candidates containing a nitrogen functionality attached to an aromatic ring.

\section{Acknowledgments}

This work was supported by KAKENHI, a Grant-in-Aid for Scientific Research (C) (23590001), the Cabinet Office, Government of Japan through its "Funding Program for Next Generation World-Leading Researchers", Tohoku University G-COE program 'IREMC', a JSPS predoctoral fellowship to Y.I., Japan Tobacco Inc. to H.C., and Banyu Life Science Foundation International.

\section{References}

1. Cho, H.; Murakami, K.; Nakanishi, H.; Isoshima, H.; Hayakawa, K.; Uchida, I. Regioselective synthesis of several heterocyclic fused azepines using diisobutylaluminum hydride. Heterocycles 1998, 48, 919-927.

2. Cho, H.; Iwama, Y.; Sugimoto, K.; Kwon, E.; Tokuyama, H. Regiospecific synthesis of unsubstituted basic skeletons of heterocycles containing nitrogen neighboring an aromatic ring by the reductive ring expansion reaction using diisobutylaluminum hydride. Heterocycles 2009, 78, $1183-1190$.

3. Cho, H.; Iwama, Y.; Sugimoto, K.; Mori, S.; Tokuyama, H. Regioselective synthesis of heterocycles containing nitrogen neighboring an aromatic ring by reductive ring expansion using diisobutylaluminum hydride (DIBALH) and studies on the reaction mechanism. J. Org. Chem. 2010, 75, 627-636.

4. Sasatani, S.; Miyazaki, T.; Maruoka, K.; Yamamoto, H. Diisobutylaluminum hydride. A novel reagent for the reduction of oximes. Tetrahedron Lett. 1983, 24, 4711-4712.

5. Cho, H.; Murakami, K.; Nakanishi, H.; Fujisawa, A.; Isoshima, H.; Niwa, M.; Hayakawa, K.; Hase, Y.; Uchida, I.; Watanabe, H.; et al. Synthesis and structure-activity relationships of 5,6,7,8-tetrahydro- $4 H$-thieno[3,2-b]azepine derivatives: Novel arginine vasopressin antagonists. J. Med. Chem. 2004, 47, 101-109. 
6. Cho, H.; Sugimoto, K.; Iwama, Y.; Mitsuhashi, N.; Okano, K.; Tokuyama, H. Regiospecific rearrangement of hydroxylamines to secondary amines using diisobutylaluminum hydride. Heterocycles 2011, 82, 1633-1644.

7. Ortiz-Marciales, M.; Rivera, L.D.; Jesús, M.D.; Espinosa, S.; Benjamin, J.A.; Casanova, O.E.; Figueroa, I.G.; Rodriguez, S.; Correa, W. Facile rearrangement of $O$-Silylated Oximes on reduction with boron trifluoride/borane. J. Org. Chem. 2005, 70, 10132-10134.

8. Rerick, M.N.; Trottier, C.H.; Daignault, R.A.; de Foe, J.D. The lithium aluminum hydride-aluminum chloride reduction of oximes. Tetrahedron Lett. 1963, 4, 629-634.

9. Brown, H.C.; Yoon, N.M. Selective Reductions. X. Reaction of aluminum hydride with selected organic compounds containing representative functional groups. comparison of the reducing characteristics of lithium aluminum hydride and its derivatives. J. Am. Chem. Soc. 1966, 88, 1464-1472.

10. Ashby, E.C.; Prather, J. The composition of "mixed hydride" reagents. A study of the Schlesinger reaction. J. Am. Chem. Soc. 1966, 88, 729-733.

11. Ashby, E.C.; Cooke, B. The mechanism of mixed hydride reductions. Effects of reagent composition, nature of halogen, and solvating ligand on the mechanism of epoxide reduction. J. Am. Chem. Soc. 1968, 90, 1625-1630.

12. Orlova, E.K.; Kucherova, N.F. Reduction of oximes with sodium bis(2-methoxyethoxy)aluminum hydride. Khim. Geterotsikl. Soed. 1980, 6, 853.

13. Orlova, E.K.; Sharkova, N.M.; Meshcheryakova, L.M.; Zagorevskii, V.A.; Kucherova, N.F. Synthesis of 2,3,4,5-tetrahydro-1,5-benzox(and thi)azepines and their utilization for the preparation of condensed indoles. Khim. Geterotsikl. Soed. 1975, 9, 1262-1266.

14. Verhoest, P.R.; Hoffman, R.L.; Corbett, J.W.; Ennis, M.D.; Frank, K.E.; Fu, J.-M. Substituted aryl 1,4-pyrazine derivatives. US 2003/0144297 A1, 2003.

15. Watanabe, K.; Yamagiwa, N.; Torisawa, Y. Cyclopentyl methyl ether as a new and alternative process solvent. Org. Process Res. Dev. 2007, 11, 251-258.

16. Watanabe, K.; Kogoshi, N.; Miki, H.; Torisawa, Y. Improved Pinner reaction with CPME as a solvent. Synth. Comm. 2009, 39, 2008-2013.

Sample Availability: Samples of the compounds $\mathbf{2} \mathbf{a}-\mathbf{h}$ are available from the authors. The primary amines 3a is reported in the patent [14].

(C) 2012 by the authors; licensee MDPI, Basel, Switzerland. This article is an open access article distributed under the terms and conditions of the Creative Commons Attribution license (http://creativecommons.org/licenses/by/3.0/). 